\title{
TRANSFORMASI NILAI PENDIDIKAN KEBERAGAMAAN PADA GENERASI MILENIAL
}

\author{
Jamal Ghofir \\ Institut Agama Islam Nahdlatul Ulama (IAINU) Tuban. \\ e-mail: jamalghofir@stitmatuban.ac.id \\ Hibrul Umam \\ Institut Agama Islam Nahdlatul Ulama (IAINU) Tuban. \\ e-mail: hibrulumam81@gmail.com
}

\begin{abstract}
Abstrak
Keragaman dalam keberagamaan adalah bagian yang tidak terpisahkan dalam konteks berbangsa dan bernegara. Keragaman yang hadir di sisi kehidupan sosial penting untuk dijaga. Terutama dalam hal memahami keragaman dalam generasi milenial. Generasi muda ini akan menjadi ujung tombak estafet kepemimpinan dalam mengawal peradaban di Nusantara ini. Oleh karena itu transformasi nilai pendidikan agama pada generasi melenial adalah suatu keharusan. Mahasiswa, Pelajar, Santri merupakan bagian dari komunitas kaum muda tersebut yang merupakan kelompok strategis perubah peradaban serta potensial sebagai pengemban misi profetis di masa yang akan datang, perlu kita perhatikan dengan seksama. Mereka jumlahnya sedikit akan tetapi sejarah telah mencatat bahwa perubahan yang ada di negeri ini dan dunia, berawal dari keberanian diri mereka untuk menghadapi tantangan dan kecerdasan intelektual mereka yang mendorong terwujudnya konsolidasi gerakan di manapun berada. Sebenarnya dalam perspektif dimensi agama, semua ajaran agama mengandung klaim kebenaran yang bersifat universal. Namun pada realitanya hal ini memungkinkan terjadi ambiguitas dalam interpretasi menurut tingkat pemahaman, penghayatan, dan moralitas-spiritualitas penganutnya, sehingga memunculkan potensi konflik antar umat beragama.
\end{abstract}

Kata Kunci: Transformasi, Nilai Pendidikan Agama, Generasi Milenial

\section{PENDAHULUAN}

Generasi muda adalah kelompok sosial yang sedang dalam proses mencari identitas. Oleh karena itu, generasi muda perlu memperoleh panduan dalam membentuk pengalaman baru tentang tata cara hidup berbangsa dan bernegara yang dilandasi oleh keyakinan terhadap ajaran agama masingmasing. Berkenaan dengan itu, perlu dilakukan kegiatan bersama sebagai wadah untuk memperkuat komitmen generasi muda terhadap ajaran agamanya masing-masing yang selaras dengan upaya memperkuat komitmen mereka terhadap keutuhan Negara Kesatuan Republik Indonesia.

Pembangunan suatu bangsa tidak lepas dari pembangunan suatu generasi. Dan suatu generasi bangsa tidak bisa lepas dari generasi sebelum dan sesudahnya. Karena itu, pembangunan suatu bangsa tidak bisa dipisahkan dari pembinaan generasi mudanya. Dalam sejarah bangsa Indonesia, peran generasi muda sangat prinsip dan menentukan. Kebangkitan Nasional 1908, berdasarkan sejarah, tonggak awal Kebangkitan Nasional diawali berdirinya Organisasi Budi Oetomo tahun 1908. Organisasi yang dimotori oleh para mahasiswa Stovia, sekolah kedokteran yang didirikan 
Belanda. Demikian juga Sumpah Pemuda 1928, di seponsori oleh Soepomo, Mohammad Hatta, dan Sutan Syahrir, yang sudah aktif berdiskusi tentang masa depan negaranya ketika mereka masih belajar di Benua Eropa.

Sebagai penerus estafet kepemimpinan negeri tercinta ini, generasi muda yang diwarisi memimpin masyarakat yang pluralistik, beragam suku bangsa, adat-istiadat, bahasa, budaya dan agama, harus memperkaya diri dengan pengalaman memimpin, memperluas wawasan, dan pengalami menghadapi dunamika kehidupan yang berada dalam peradaban global.

\section{ISI DAN PEMBAHASAN}

Pluralitas agama merupakan salah satu kharakteristik dari bangsa Indonesia yang heterogen. Sehingga tidak dapat dipungkiri, pluralitas agama ini memiliki potensi dan peran sangat besar dalam proses integrasi dan pembangunan, di samping juga mengandung potensi terjadinya konflik, disintegrasi bangsa. Ketika melihat masing-masing agama memiliki klaim kebenaran absolut dan muatan emosi keagamaan yang menjadi dasar interaksi primer. Konflik atas dasar perbedaan agama bisa disebabkan, baik oleh ajaran agama itu sendiri, kualitas moral-spiritual penganutnya, maupun latar belakang budaya, serta adanya rasa kegamangan dalam bidang sosial, ekonomi, politik, dan budaya.

\section{A. Memahami Pluralitas Keberagamaan}

Agama, baik itu agama samawi, agama filosofis dan semua sistem lainnya, selalu mengasumsikan kemutlakan (doktrin) disamping metode yang tertuang dalam sistem ajaran, ritual dan tuntunan. Dalam kemutlakannya itu, suatu agama berfungsi sebagai pegangan dan tuntunan hidup yang memerlukan kadar kepastian yang tinggi, dan memberikan kepastian itulah fungsi pegangan atau tuntunan.

Menurut Azra, pluralisme diakui oleh Islam dalam kerangka normatif dan historis. Oleh karena itu, tegas Azra, usaha atau upaya untuk menciptakan sebuah masyarakat yang tidak plural, masyarakat yang monolitik, yang tunggal, itu merupakan upaya yang sia-sia. Sikap yang paling tepat adalah dengan mengembangkan sikap saling menghormati, toleran, dan menghargai pluralisme (Azra, 2005 : 149).

Karena itu, agama dalam maknanya yang paling esensial merupakan mengkonsepsikan satu pemahaman tentang pesan akan nilai-nilai universal sebagai rahmat seluruh umat dan bukan kekerasan maupun peperangan yang terkandung di dalamnya. Semangat inilah yang dikandung oleh setiap agama mengajarkan kedamaian, cinta kasih dan jauh dari kekerasan. Rentannya konflik yang berlatar belakang agama telah menjadikan problem kemanusiaan semakin jauh dari penyelesaian. Karena tindakan destruktif yang dilakukan manusia sering kali mengatasnamakan agama, maka 
agama lambat taun akan kehilangan ruh sucinya yang berakhir pada kaburnya nilai-nilai kemanusiaan yang dikandungnya.

Secara historis setiap agama dan kepercayaan hadir secara bergantian. Namun bukan berarti hadirnya agama atau kepercayaan baru dengan sendirinya menghapus, menghilangkan, dan menyingkirkan agama dan kepercayaan sebelumya. Oleh karena itu menjadi suatu kewajaran apabila dalam setiap masyarkat terdapat berbagai agama dan kepercayaan yang beraneka ragam bentuknya. Pluralisme harus difahami sebagai pertalian sejati kebhinekaan dalam ikatan-ikatan keadaban (genuine engagement of diversities within the bonds of civility) (Rachman, 2001 : 31).

Pluralitas keberagamaan umat manusia telah menorehkan sejarahnya sendiri yang multiwarna. Terjadinya peperangan yang menghilangkan nyawa manusia, harta, persaingan serta saling mencurigai merupakan bentuk dari anatoni wajah yang suram, yang dipicu oleh realitas pluralitas agama, yang sampai detik ini masih menampakan perwujudannya. Sejarah kelam tersebut telah menyadarkan sebagaian umat beragama untuk menggali kembali pentingnya nalar agama yang " melampaui " pemahaman-pemahaman dari klaim kebenaran yang "tradisional".

Adanya kesadaran sebagaian umat manusia dengan adanya pluralitas keberagamaaan, menjadikan fase utama dari sebuah pengharapan akan lahirnya dialog (tasyawur) antar umat beragama. Sepanjang abad dua puluh, kesadaran pluralitas itu tumbuh subur sehingga berbagai forum dialog terbentuk. Sebuah kesadaraan yang tumbuh akan pluralitas keberagamaan, dibarengi dengan terbentuknya berbagai forum dialog antar umat beragama, merupakan perwujudan nyata akan peradaban baru umat manusia.

Mendeskripsikan idialitas ajaran agama yang penuh dengan ajaran kebaikan dan realitas konflik berbasis agama sebagaimana yang terlihat dalam fakta sejarah ternyata bukan hal yang mudah. Meminjam istilah Charles Kimbali, kita tidak bisa serta merta menuduh agama sebagai biang masalah. Bagi Kimbali, jawaban atas persoalan ini sangat dipengearuhi bagaimana orang memahami hakekat agama itu sendiri. Agama harus difahami dalam konteks relasinya dengan kehidupan yang berbasis realitas (Kimbali, 2003 : 35). Implikasinya, definisi, pengertia, dan pemahaman agama sangat beragam, tergantung kepada siapa yang mendefinisikannya (Rakhmat, $2006: 20)$.

Sebuah realitas yang tidak dapat dihindari, bahwasannya dalam kehidupan agama yang berbagai bentuk warnanya, perbedaan tidak bisa dielakkan lagi. Dengan adanya perbedaan tersebuat dapat mengakibatkan suatu umat beragama memusuhi bahkan memerangi umat agama yang lain, sehingga menimbulkan suatu kondosi yang tidak kondusif serta suasana yang tidak harmonis dan toleran. 
Dasar toleransi umat beragama, tidak berarti ajaran agama yang satu dengan ajaran agama yang lain dicampur adukkan. Tetapi dengan dasar hidup yang mengedepankan toleransi dalam kehidupan berkelompok dan bermasyarakat, tradisi-tradisi keagamaan yang dimiliki setiap individu menjadi komulatif dan kohesif yang menyatukan keragaman interpretasi dan sistem keyakinan keagamaan.

Sebagai bagian yang tak terpisahkan dari pembangunan, masyarakat harus mengupayakan terbentuknya suatu kondisi yang kondusif dengan memberikan peluang berkembangnya iklim saling mengerti atau pengertian antar warga masyarakat yang memiliki perbedaan. Hal ini sangatlah penting, sebab sebesar apapun bentuk modal material pembangunan, bila suasana sosial kemasyarakatan tidak kondusif, maka pelaksanaan serta keberhasilannya tidak akan optimal. Kesadaran ini menjadikan salah satu pendorong bagi upaya terwujudnya toleransi umat beragama. Dengan toleransi seperti inilah, diharapkan terwujudnya suatu tatanan masyarakat dan terwujudnya kerjasama yang harmonis antar seluruh warga masyarakat tanpa memandang perbedaan sebagai bentuk hambatan dalam kerjasama kemasyarakatan.

Terpeliharanya persatuan dan keasatuan adalah dambaan sekaligus tantangan bagi negaranegara modern, termasuk Indonesia. Ia selalu di upayakan agar tetap terpelihara dengan baik, karena ketentraman masyarakat dan stabilitas negara sangat tergantung padanya. Rasulullah telah mewariskan pada kita sebuah sistem yang mengatur segala aspek kehidupan. Sistem yang berisi pondamen prinsipil, kaidah-kaidah universal, aturan-aturan main yang dengannya memungkinkan kita memiliki karaktristik independen, tegak berdiri diatas landasan manhaj akidah yang memiliki tabiat, keistimewaan dan integritas yang mumpuni dan mengungguli sistem barat kotemporer.

\section{B. Kerukunan antar Umat Beragama}

Salah satu aspek penting yang seharusnya terus menerus diperjuangkan dalam kehidupan sosial kemasyarakatan di Indonesia adalah kerukunan. Diperjuangkan karena kerukunan tidak bisa terbentuk begitu saja. Kerukunan membutuhkan ihtiar secara serius dan kemauan untuk menjaganya. Kerukunan yang sudah terbangun bisa saja terkoyak dan hancur berantakan karena memudarnya kesadaran terhadap kerukunan itu sendiri (Naim, 2014 : 123).

Islam telah mengajarkan mengenai kesatuan umat yang bermuara pada kesadaran bahwa manusia diciptakan oleh satu Tuhan, Islam lebih lanjut mengajarkan pada umatnya agar dalam hidup bermasyarakat hendaknya semua warga masyarakat harus dipandang sama, tidak ada lagi perbedaan yang nantianya menghambat terbentuknya sebuah kesadaran bermasyarakat dalam menghadapi keberagaman, baik suku, ras, golongan maupun agama. Ajaran dan tardisi agama yang paling hakiki sesungguhnya bisa dilihat pada nilai-nilai kemanusiaan yang terkandung di dalamnya (Nasr, 2003 : 189),. Salah satu bentuk elaborasinya adalah pengakuan yang tulus terhadap kesamaan 
dan kesatuan umat. Semua manusia adalah sama dan berasal dari sumber yang satu, yakni Tuhan. Dalam ajaran agama Islam yang membedakan posisi manusia di hadapan Tuhan hanyalah prestasi yang diraih dan kuwalitas ketakwaannya, berkaitan denga takwa hanya Allah SWT yang mengetahui dan memiliki wewenang atau hak prerogratif dalam melakukan penilaian. Sebuah penghargaan terhadap niali-nilai kemanusiaan ini diejawantahkan dengang keharusan saling menghormati sesama manusia tanpa melihat jenis kelamin, gender, ras, suku, dan golongan, serta agama. Karena itu, setiap agama pasti memiliki dua aspek ajaran, ketuhanan (vertikal) dan kemanusiaan (horizontal).

Sebagaimana bangunan peradaban yang sudah dibangun di Madinah oleh Nabi Muhammad Saw yaitu dengan mewujudkan sebuah tatanan yang tertulis sebagai produk hukum yaitu Piagam Madinah. Dalam konstitusi Madinah, Nabi menetapka orang-orang Yahudi sebagai umat, dengan mengintegrasikan mereka ke dalam umat Muslim yang sudah terbentuk. Kemudian istilah ini diterapkan pada orang-orang Kristen. Salah satu tujuan utama konstitusi Madinah adalah menciptakan semangat komunitas dari berbagai segmen kesukuan dan keagamaan masyarakat yang berbeda-beda (Aslan, $2004: 286$ ).

Terbentuknya kesadaran inilah, diharapkan terciptanya tatanan masyarakat yang egaliter, ekslusif. Tidak ada lagi perbedaan yang menghatarkan pada kehancuran diakibatkan sudut pandang yang sempit. Terbentuknya kesadaran dalam masyarakat, bahwasanya manusia merupakan makhluk yang sama baik di mata hukum dalam tatanan suatu negara, maupun dihadapan Allah dalam konteks yang lebih makro, merupakan suatu keharusan.

\section{Generasi Milenial dalam Pemahaman}

Pemuda merupakan ujung tombak terhadap perubahan dan perbaikan masyarakat kedepan. Kepemimpinan merupakan karakter yang nantinya akan berpengaruh besar terhadap proses kepedulian seorang Muslim pada problematika umat dan masa depan bangsa. Kalau kita lihat kondisi kaum muda saat ini pada umumnya, mereka cenderung bersifat individualis dan mudah terseret kepada hal-al yang pragmatis-taktis. Padahal peradaban dan masa depan bangsa ini sangat tergantung pada kualitas kepribadian kaum mudanya. Kita masih ingat kata-kata Bung Karno tentang pemuda "bahwa jika ada sepuluh pemuda yang berkualitas kepribadiannya dan berjiwa pemimpin maka tidak lama lagi dunia akan dia rubah”.

Generasi Melenial yang merupakan bagian dari komunitas kaum muda yang terdidik merupakan kelompok strategis perubah peradaban serta potensial sebagai pengemban misi profetis di masa yang akan datang, perlu kita perhatikan dengan seksama. Mereka jumlahnya sedikit akan tetapi sejarah telah mencatat bahwa perubahan yang ada di negeri ini dan dunia, berawal dari 
keberanian diri mereka untuk menghadapi tantangan dan kecerdasan intelektual mereka yang mendorong terwujudnya konsolidasi gerakan dimanapun berada.

Di Indonesia, fenomena lahirnya kaum terpelajar telah mendorong lahirnya organ-organ pergerakkan kemerdekaan di awal abad dua puluhan. Tokoh-tokoh penting pergerakan tersebut kemudian menjadi founding fathres negara kesatuan Republik Indonesia. Banyak pengamat pergerakan di Indonesia menyebutkan, lahirnya kaum terpelajar di Indonesia akan menjadi pendorong peradaban Indonesia baru. Peradaban Indonesia baru merupakan awal munculnya gerakan pembumian Islam di Indonesia dalam cita-citanya mewujudkan masyarakat madani.

Sejarah bangsa ini telah mencatat bahwa mahasiswa/pelajar/santri dengan gerakannya memiliki peran dan andil besar dalam proses perubahan yang dinamis pada kehidupan rakyat dan bangsa Indonesia. Hal inilah yang sesungguhnya menjadikan mahasiswa, pelajar, dan santri menyandang atribut agent of change. Perubahan dan dinamika kehidupan bernegara yang tentunya membawa kompleksitas persoalan menuntut adanya kearifan sikap dalam mengatasi setiap persoalan yang ada, hal tersebut sesungguhnya juga membutuhkan sense of pulic crisis. Artinya bahwa mahasiswa, pelajar,dan santri harus memiliki kepekaan terhadap persoalan-persoalan publik. Sebab bagaimanapun mahasiswa, pelajar, santri sesungguhnya adalah sebagian dari rakyat yang semestinya mampu menjadi avant garde (pelopor) bagi terwujudnya suatu tatanan kehidupan berbangsa dan bernegara yang baik, adil dan sejahtera sebuah tanggungjawab bersama tentunya untuk mewujudkan hal tersebut tidak terkecuali mahasiswa, pelajar, santri dan seluruh lapisan msyarakat.

Dalam mewujudkan hal tersebut sangat diperlukan suatu pemahaman keberagamaan bagi generasi milenial dalam hal pluralitas keberagamaan. Nilai-nilai pendidikan keberagaman benarbenar harus diperkuat dan dikembangkan pada wilayah institusi pendidikan. Pluralitas adalah sebuah keniscayaan dalam kehidupan ini. Allah menciptakan alam ini di atas sunah pluralitas dalah sebuah kerangka kesatuan. Pluralitas pada hakikatnya merupakan relitas kehidupan itu sendiri, yang tidak bisa dihindari dan ditolak. Karena pluralitas adalah sunnatullah, maka eksistensi atau keberadaannya harus diakui oleh setiap manusia. Namun pengakuan ini dalam tataran realitas belum sepenuhnya seiring dengan pengakuan secara teoritik dan kendala-kendala masih sering dijumpai di lapangan (Pohan, 2014 : 240).

Oleh karena itu, adanya kendala dalam tataran realitas membutuhkan ruang dialektika pemahaman keragaman dalam keberagamaan generasi melenial secara masif. Baik dalam ruang institusi pendidikan atau edukasi lainya. Sebagaimana penguatan dialog antar generasi muda lintas umat beragama. Karena dalam konteks sejarah perkembangan dan kebudayaan Indonesia tidak bisa dilepaskan dari pengaruh agama-agama besar yang ada dan berkembang di Indonesia. Mula-mula 
dengan agama Hindu, disusul agama Budha, Islam, dan kemudian Kristen, baik Protestan maupun Katolik (Ghazali, 2009 : 102). Dengan keberadaan agama besar tersebut sudah memperlihatkan kepada kita, bahwasanya kemajemukan di Indonesia adalah sebuah fakta yang tidak dapat dipungkiri lagi.

Begitu juga pemahaman akan pentingnya kerja-kerja sosial yang menyentuh pada wilayah kemanusiaan. Manusia merupakan makhluk sosial, yaitu makhluk yang hidup berdampingan dengan makhluk lainya dan saling membutuhkan antara satu dengan yang lainya. sebagai makhluk yang hidup bermasyarakat, manusia senantiasa berhubungan dengan masyarakat lain guna memenuhi kebutuhan hidupnya (Basyir, 1985 :7).

Berkaitan dengan hal tersebut dalam perspektif Islam, agama Islam memandang bahwa masyarakat merupakan rekan kerja, teman seperjuangan, teman dalam dalam melakukan kerjasama demi kepentingan bersama. Tanpa membedakan apakah dia beragama Islam maupun tidak beragama Islam (non muslim). Bagi Islam kerjasama dan tolong menolong merupakan menjadi suatu keharusan bagi umat manusia yang hidup bersama-sama di muka bumi ini (Ghofir, 2017 : 135). Saya meyakini begitu juga halnya dengan agama-agama lain, pasti memiliki perspektif yang sama dalam sudut pandang kerja-kerja kemanusiaan. Dengan demikian, dapat menjadi pegangan bagi kita dalam menanamkan dan mentransformasikan nilai pendidikan keragaman dalam keberagamaan bagi generasi milenial.

\section{Ruang Transformasi Pendidikan Keberagamaan}

Di tengah mengencangnya identitas agama dan diskursus keagamaan di Indonesia, kaum muda dengan kadar yang berbeda-beda masih tetap bertemu pada ruang yang sama yaitu sebagai anak bangsa dalam mewujudkan tatanan kehidupan dalam berbangsa, bernegara, dan beragama yang lebih baik. Oleh karena itu, penguatan dalam pengembangan kualitas Sumber Daya Manusia (SDM) menjadi salah satu parameter dalam meningkatkan kemajuan kehidupan di berbagai aspek. Manusia yang berkualitas memiliki potensi yang lebih besar untuk diajak bersama-sama membangun kehidupan yang lebih baik dan bermutu. Sementara sumber daya manusia yang kurang bermutu, tentu saja sulit untuk diajak bersama-sama mewujudkan idealitas kehidupan yang lebih baik. Kualitas sumber daya manusia mempengaruhi terhadap sikap, mentalitas, pandangan hidup, dan segala hal yang berkaitan dengan diri, lingkungan masyarakat, dan seluruh aspek kehidupan. Meningkatkan kualitas kehidupan antarumat beragama juga tidak bisa mengabaikan terhadap peran penting peningkatan kualitas manusianya (Naim, 2014:226-227).

Dalam peningkatan pemahaman keragaman dalam keberagamaan, kualitas sumber daya manusia menjadi penting. Ada banyak cara dalam upaya peningkatan tersebut. Diantaranya adalah melalu intitusi pendidikan, sebab pendidikan diyakini sebagai institusi yang paling efektif untuk 
mewujudkannya. Hal ini disebabkan karena manusia yang berkualitas itu memiliki kreativitas tinggi. Ia akan selalu memiliki gagasan dan ide yang kreatif dalam menyikapi perkembangan zaman. Sebagaimana disampaikan Mujamil Qomar bahwasanya dalam situasi persaingan yang ketat, seseorang dituntut berpikir yang sangat serius dan bertindak tepat sasaran. Hal ini mulai dari karya sederhana hingga teknologi modern (Qomar, 2012 :72-73).

Keragaman merupakan sebuah keniscayaan yang selalu mewarnai kehidupan manusia. Keberagaman adalah wujud dari perbedaan-perbedaan yang berangkat dari fitrah manusia atau faktor bawaan sebagai anugrah dari Allah. Pada hakikatnya keberagaman jika dipandang dan disikapi secara positif merupakan sebuah anugrah dan manifestasi bagi setiap individu dalam kelompok sosial yang akan saling melengkapi, karena pada dasarnya manusia adalah makhluk sosial yang saling membutuhkan antara satu dengan yang lain. Tetapi apabila keberagaman itu dipahami sebagai penghambat dan masalah bagi individu maupun kelompok sosial lain, maka perbedaan itu akan menjadi sebuah konflik sosial yang berdampak pada pengucilan, kekerasan bahkan pemusnahan pada kelompok minoritas (Mutakhim, 2016 : 175-176).

Oleh karena itu, ruang transformasi pendidikan keagamaan bagi generasi milenial menjadi sangat penting untuk diprioritaskan, dalam upaya memperkuat kualitas sumberdaya manusia dalam penguatan pemahaman keragaman dalam keberagamaan. Adapun ruang transformasi tersebut diantaranya adalah :

\section{Institusi Pendidikan}

a. Sekolah

Kita memahami bahwasanya bangsa Indonsia merupakan bangsa yang memiliki beragam budaya, bahasa, agama, suku serta etnik yang tersebar diberbagai pelosok negeri. Para pendiri bangsa Indonesia secara bijak menyadari bahwa fakta sosial ini adalah suatu anugrah yang perlu disyukuri dan dijaga sebagai warisan bagi generasigenerasi berikutnya. Nilai keragaman bangsa ini secara jelas bisa kita cermati sebagaimana yang disimbolkan pada lambang Garuda, yang memuat tulisan Bhinneka Tunggal Ika, yang berarti berbeda-beda tetapi tetap satu. Walupun demikian, praktik pengelolaan keragaman tidak selalu bertahan sebagaimana idealnya. Ada upaya untuk menjaga keragaman itu tetapi sering pula muncul persoalan yang antara lain diakibatkan oleh masih adanya sikap penolakan terhadap kenyataan keragaman. Tentu saja kenyataan itu menjadi tantangan dalam mengelola bangsa yang besar ini (Retnawati. 2016 :87).

Lebih lanjut dijelaskan bahwasanya pemahaman mengenai keragaman bisa dibangun sejak dini melalui antara lain pendidikan formal di sekolah. Sebagaimana kita fahami, guru adalah pendidik yang berperan besar dalam membentuk generasi penerus bangsa. 
Oleh karena itu, peran guru sangatlah penting dalam ikut membentuk generasi muda yang berpola pikir terbuka untuk mampu menerima dan menghargai kenyataan kemajemukan di masyarakat. Sebaliknya, pengelolaan pendidikan ecara keliru bisa saja turut menciptakan generasi bangsa yang berpola pikir sempit.

Pendidikan menjadi kunci utama dalam pembentukan karakter anak bangsa. Pendidikan yang berkualitas akan mampu membentuk generasi penerus yang siap dan mampu merespon persoalan sosial kemasyarakatan. Mereka tidak akan mudah menerima informasi yang belum tentu memiliki nilai kebenaran. Misalnya pendididikan multikultur menawarkan satu alternatif melalu penerapan strategi dan konsep pendidikan yang berbasis pada pemanfaatan keragaman yang ada di masyarakat, khususnya yang ada pada siswa, seperti keragaman etnis, budaya, bahasa, agama, status sosial, gender, dan masih banyak yang lain.

Pada ruang pendidikan inilah peranan guru sangat signifikan dalam rangka membuka ruang pola pikir peserta didiknya. Kita sangat memahami bahwasanya peserta didik tidak hanya belajar dari perkataan guru tetapi juga melihat praktik kehidupan yang dijalani oleh guru tersebut. Oleh karena itu, guru yang memiliki pengetahuan yang luas dan memiliki pola pikir yang terbuka seyogyanya mampu memberikan suatu pendidikan atau pemahaman keragaman yang ada disekitar kita. Cara pandang yang luas dan terbuka akan memiliki pengaruh yang besar bagi proses transfer nilai pendidikan dalam keragaman bagi generasi milenial.

Di samping itu juga, kurikulum dan akses kegiatan yang konstruktif juga harus dikembangkan. Penguatan nasionalisme kebangsaan menjadi titik penting dalam memasuki ruang kehidupan peserta didik. Karena berbicara nasionalisme juga berbicara tentang seluruh elemen anak bangsa yang ada di suatu negara tanpa adanya sekat perbedaan. Baik perbedaan suku, ras, agama, bahasa, sosial dan lainnya. Setiap guru seyogyanya senantiasa memberikan ruang pemahaman dalam perbedaan, terutama dalam kurikulum materi pembelajaran.

Ruang literasi atau perpustakaan menjadi ruang peradaban bagi siswa. Oleh karena itu, sekolahan harus memiliki strategi bagaimana siswa dapat dengan mudah dan mau mengakses buku-buku yang ada di perpustakaan. Koleksi buku tidak hanya terfokus pada mata pelajaran pendidikan saja. Namun juga buku-buku lain yang nantinya menjadi rujukan dalam memahami keragaman yang ada. Yang menjadi kendala saat ini adalah belum adanya kesadaran literasi siswa terhadap pentingnya dunia baca. Sebagaimana yang telah penulis lakukan sebuah riset sederhana tentang budaya membaca siswa. Siswa 
lebih mengutamakan berkumpul bersama teman-temanya di kantin dari pada mengakses dan menelaah buku-buku yang ada diperpustakaan pada waktu istirahat.

Begitu juga pada aktifitas kegiatan kesiswaan, ruang transformasi nilai keragamaan juga seyogyanya digalakaan. Misalnya kegiatan keagamaan yang lebih menekankan pada wilayah nilai agama dan implementasi kehidupan, pemahaman dan implementasi nilainilai toleransi (tasamuh) pada siswa. Penguasaan wawasan keilmuan dengan kegiatan seminar atau dialog kebangsaan. Dengan kegiatan tersebut, siswa akan lebih terbuka dalam menyikapi keragaman-keragaman yang hadir di tengah-tengan masyarakat Indonesia.
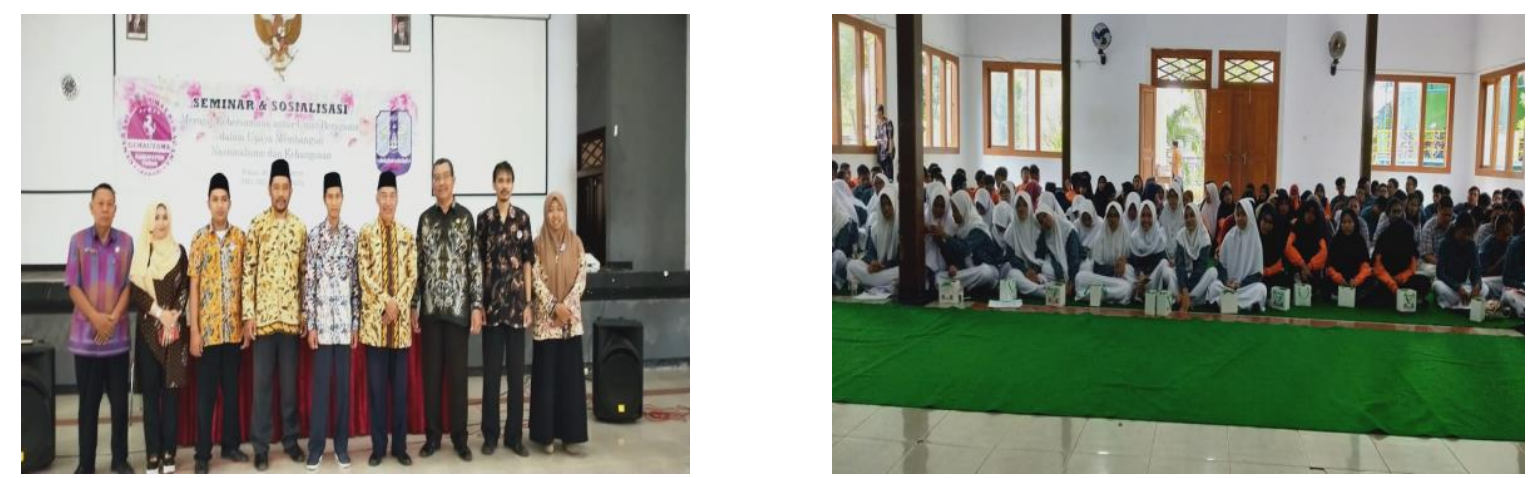

Foto : Seminar Merajut Kebersamaan antar Umat Beragama di SMAN 1 Tuban

b. Kampus

Kampus sebagai ruang pengasahan intelektual bagi generasi milenial menjadi tumpuan saat ini. Istilah kampus sudah sangat familier sekali tentunya dikalangan civitas akademika. Kampus merupakan deretan gedung yang ada di perguruan tinggi sebagai sarana tempat kuliah bagi mahasiswa. tetapi pengertian gedung di atas apabila disandingkan dengan kampus untuk era modern ini sepertinya sudah tidak relevan lagi, seiring dengan perkembangan ilmu komunikasi. Alasan ini berdasarkan alasan masingmasing individu tentang makna kampus itu sendiri. Ada sebagian kelompok yang menyatakan bahwasanya kampus adala tempat untuk belajar, berdiskusi, berkontemplasi. Ada pula yang menyatakan bahwasanya pengertian kampus adalah ruang dialektika dalam membuka alam fikiran untuk menjadi manusia yang memiliki pengetahuan yang lebih luas.

Di sinilah ruang-ruang diskusi dikembangkang oleh mahasiswa dalam rangka penguatan dan penambahan wawasan intelektual bagi mereka. Kampus memiliki ruang gerak yang lebih luas dalam mentransformasikan nilai-nilai keragaman dalam berbangsa dan bernegara. Oleh karena itu, kegiatan-kegiatan kampus lebih menjadi menarik bagi khalayak umum. 
Oleh karena itu, kampus sebagai ajang dalam pengembangan potensi mahasiswa juga harus berbenah dalam kegiatan-kegiatan yang lebih bersifat ilmiah. Karena keberadaan mahasiswa menjadi tumpuan dalam estafet kepemimpinan masa depan. Ruang-ruang ilmiah diantaranya adalah seminar, dialog, bedah buku, pengabdian masyarakat, riset dll. Kegiatan-kegiatan tersebut merupakan ruh intelektualitas yang ada di setiap kampus.

Begitu juga kampus sebagai media dalam transformasi nilai pendidikan keragaman pada diri mahasiswa. Mahasiswa sebagai generasi milenial memiliki tanggungjawab yang besar dalam usaha memperkuat ikatan persatuan dan kesatua dalam perbedaan. Sebab, mahasiswa memiliki sudut pandang pengetahuan yang lebih luas dengan literaur-literatur pengetahuan yang mereka dapatkan baik di ruang perkulian, perbustakan, Unit Kegiatan Mahasiswa (UKM), atau ruang diskusi lainya.

Ruang-ruang diskusi tersebut juga tidak terlepas dari pemahaman mahasiswa dalam menyikapi perbedaan dalam keberagamaan. Sebagaimana disampaikan oleh K.H. Abdurrahman Wahid atau yang sering kita panggil dengan panggilan Gus Dur. Gus Dur sering mengingatkan kepada kita tentang adanya kecendrungan masih ditekankannya perbedaan-perbedaan antaragama didalam pembicaraan soal agama. Bahkan, kadangkadang dengan cara merendahkan agama lain (Ekopriyono, 2005 :1440.

Seminar, penelitian, dan dialog-dialog dalam membina kerukunan umat beragama harus terus dikembangan di lingkungan kampus. Hal ini merupakan bagian dari proses transformasi nilai keragaman keberagamaan dalam bingkai Negara Kesatuan Republik Indonesia (NKRI). Tidak dapat disangkal bahwa toleransi (tasamuh) dan kerukunan hidup umat beragama di Indonesia merupakan faktor yang sangat penting dan strategis. Tanpa adanya toleransi dan kerukunan hidup, hubungan antar umat beragama tersebut akan menjadi rawan dan mudah terganggu (Daulay, 2001 : 30).
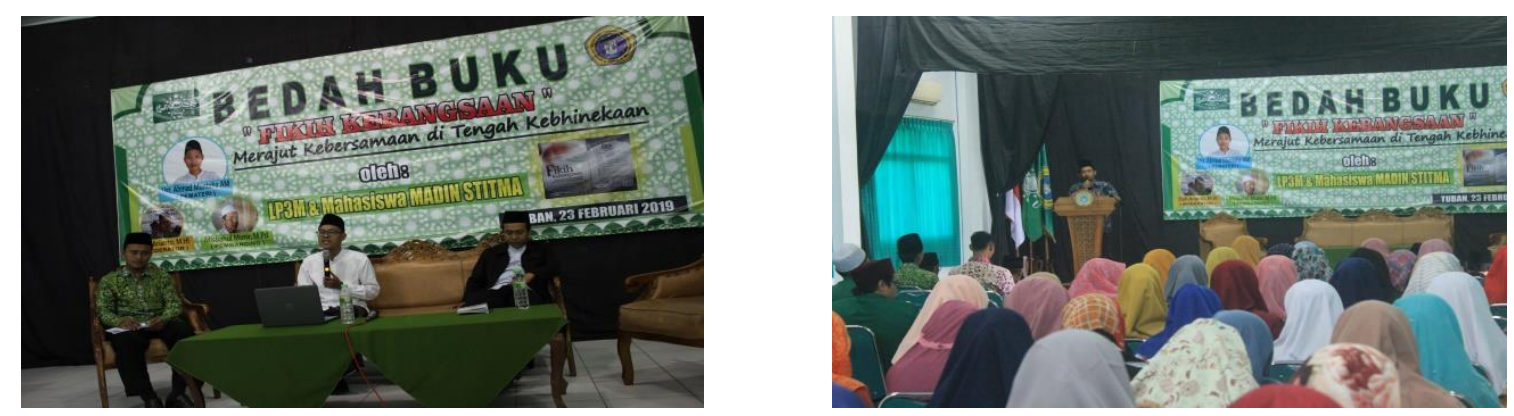

Foto : Bedah Buku Fiqih Kebangsaan di Kampus STITMA saat ini berubah nama IAINU c. Pesantren 
Pesantren merupakan khazanah peradaban Nusantara yang telah ada sejak zaman kapitayan, sebelum hadirnya agama-agama besar seperti Hindu, Budha, dan Islam. Pertemuan dengan agama tersebut Pesantren mengalami perubahan bentuk dan isi sesuai dengan karakter masing-masing agama, tetapi misi dan risalahnya tidak pernah berubah, yaitu memberikan muatan nilai spiritual dan moral pada setiap prilaku masyarakat seharihari, baik dalam kegiatan sosial, ekonomi maupun kenegaraan (Siroj, 2014 :3).

Pesantren dibalik eksistensinya yang mampu bertahan selama berabad-abad dengan karakternya yang khas, ternyata punya elemen-elemen yang terkait dengn sejarah panjang jatuh bangunya kerajaan di Nusantara-serta sepenggal kisah tentang bagaimana bangsa ini berdiri. Oleh karena itu patut kita simpulkan-setidaknya kita siratkan- sebuah keyakinan bahwa apa yang terkandung dalam dalam “perut' pesantren juga tersirat dalam keislaman Indonesia, keduanya senantiasa dalam proses relasi. Keduanya saling menjaga, juga memberi (Irawan, $2018: 7$ ).

Pondok pesantren merupakan lembaga pendidikan Islam tertua dan berakar cukup kuat di tengah-tengah masyarakat. Selain itu, pesantren mempunyai keunikan tersendiri yang berbeda dari lembaga pendidikan lain di tanah air. Salah satunya ialah sistem nilai yang dikembangkan sejak berpuluh-puluh tahun lamanya dan tetap eksis hingga sekarang (Yasid, 2018 : 13). Keberadaan Pondok Pesantren hadir bersamaan dengan penyebaran ajaran Islam yabg disebarkan oleh Wali Songo, khususnya penyebaran Islam di Tanah Jawa. Tidak dapat dinafiqkan, bahwasanya keberadaan Islam mulai berkembang di Bumi Nusantara ini, berkat jerih payah para Wali Songo yang mengemban amanah suci dalam mensyiarkan ajaran Islam. Sebagaimana Sunan Ampel dalam mendirikan Pesantren di Ampel Denta dan mampu menghasilkan santri-santri yang memiliki intelektualitas pemahaman keagamaan yang kuat dan luas, sebagai penerus perjuangan membawa misi ajaran Islam yang rahmatan lil 'alamin.

Di pesantren yang kental dengan nilai-nilai spiritual itu, diperoleh suasana ketenangan batin. Di tengah derasnya arus modernisme dan kegersangan spiritual yang melanda umat, pesantren diharapkan bisa tetap tegar dengan tradisinya yang penuh keegaliteran dan kesederhanaan. Suasana pesantren yang dihiasi dengan bacaan ayat-ayat suci, puji-pujiannya dengan bacaan dzikir, tahmid, dan tahlil kepada Tuhan,akan membuat batin semakin tentram. Di pesantren digambarkan dengan begitu jelas ikatan antara kyai dan santri sangat begitu tulus dan ikhlas. Posisi kyai dalam konteks perjuangan kemerdekaan Indonesia sudah begitu jelas, nilai-nilai nasionalisme kebangsaan, menghargai pada perbedaan sudah lama diimplementasikan. Oleh karena itu 
pesantren dengan generasi milenialnya yaitu para santri memiliki ruang yang sama dalam mendapatkan transformasi nilai pendidikan keragamaan dalam keberagamaan.

Kehidupan yang dijalani para santri sangatlah sederhana dan penuh dengan kekhidmatan dalam proses pencarian ilmu. Alumni-alumni santri sampai saat ini berada pada garis depan dalam pengawalan persatuan dan kesatuan bangsa Indonesia. Walaupun mereka dianggap sebagai kaum tradisionalis. Namun saat ini, mereka mampu membuktikan kepada khalayak dunia, bahwasanya santri memiliki ruang intelektualitas yang luas dan pengabdian dalam menjaga persatuan dan kesatuan yang tidak diragukan lagi.

\section{Kegiatan Kepemudaan}

\section{a. Multikultural Youth Cam}

Ruang transformasi nilai keberagaman dalam keberagamaan juga dapat diadakan dengan berbagai cara. Diantaranya dengan mengadakan kegiatan Kemah Multikultural Youth Cam. Kegiatan aplikatif ini diadakan dengan tujuan mempertemukan dan mengeratkan solidaritas kersamaan dalam perbedaan. Kegiatan yang terselengara diikuti oleh generasi muda lintas umat beraga dan para pelajar sebagai undangan.

Kegiatan kemah ini juga diisi dengan berbagai materi yang sudah disiapkan. Dengan merujuk pada kepentingan bersama dalam memperkuat ikatan persaudaraan antar generasi muda lintas umat beragama. Materi-materi tersebut sebagai bagian transformsi nilai keragaman dalam keberagamaan. Misalnya pemateri dari pemerintah dalam hal ini disampaikan oleh kesbangpol, materi kebangsaan disampaikan oleh kapolres, materi keberagamaan disampaikan dari kementerian agama, materi kerukunan beragama disampaikan oleh Foruk Kerukunan Umat Beragama (FKUB). Materi-materi yang sudah disampaikan selanjutnya ditajamkan dengan pembagian kelompok dan diskui. Selanjutnya diakhir kegiatan Multikultural Youth Cam diadakan Out Bond dengan tujuan memperkuat solidaritas persaudaraan antar generasi muda lintas umat beragama.
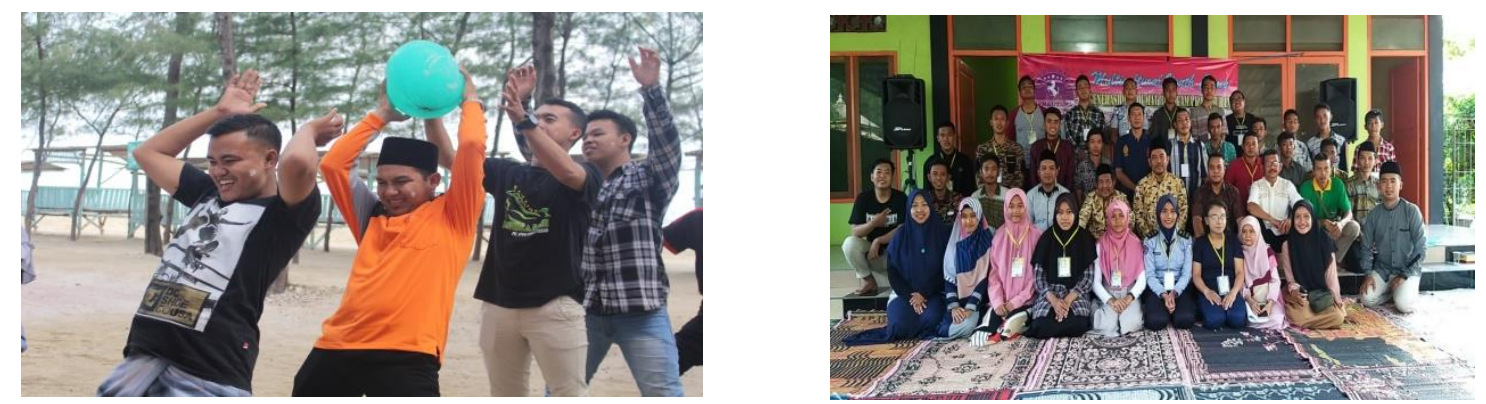

Foto : Kegiatan Multikultural Youth Cam

b. Dialog Kepemudaan 
Masyarakat Indonesia yang sangat plural baik dari segi suku budaya, ras, dan agama sereta setatus sosial merupakan kontrubusi yang luar biasa terhadap perkembangan dan dinamika dalam masyarakat Indonesia, kondisi demikian memungkinkan terjadinya benturan antar budaya, antar umat beragama, dan antar ras yang bisa memecah persatuan Negara Indonesia bila terjadi kekeliruan dalam pemahaman nilai. Nilai-nilai tersebut merupakan implementasi kehidupan dalam berbangsa dan bernegara.

Keragaman suku, bahasa, dan agama yang terdapat di wilayah Negara Kesatuan Republik Indonesia (NKRI) telah menjadikan Indonesia sebagai sebuah Negara kesatuan yang majemuk. Keragaman tersebut merupakan anugerah Tuhan Yang Maha Esa, yang harus kita syukuri. Namun apabila kemajemukan tidak ditangani dengan baik, maka akan menimbulkan kerawanan dan berpotensi konflik dalam kehidupan berbangsa dan bernegara.

Adanya perbedaan pemahaman terhadap landasan masing-masing agama atau budaya, telah memunculkan kerawanan dan potensi konflik ditengah masyarakat, sehingga hal ini dikhawatirkan akan menyebabkan pengikisan nilai-nilai keagamaan dan melemahnya rasa, paham, dan semangat kebangsaan. Lebih jauh lagi kondisi ini dikhawatirkan akan memicu konflik antar umat beragama baik yang bersifat horizontal maupun vertikal. Bersamaan dengan munculnya sentimen-sentimen suku bangsa, agama, dan ras telah menantang pemikiran kerukunan itu sendiri, terutama dalam membangun masa depan hubungan kehidupan bermasyarakat, berbangsa dan bernegara, dan beragama yang lebih baik, terbuka, adil, dan demokratis. Permasalahan yang menyangkut hubungan antar umat beragama di Indonesia belakangan ini memang sangat komplek. Hal ini tidak terlepas dari dari berbagai kepentingan seperti kepentingan ideologi, politik, ekonomi, sosial dan budaya.

Generasi muda adalah kelompok sosial yang sedang dalam proses mencari identitas. Oleh karena itu, generasi muda perlu memperoleh panduan dalam membentuk pengalaman baru tentang tata cara hidup berbangsa dan bernegara yang dilandasi oleh keyakinan terhadap ajaran agama masing-masing. Berkenaan dengan itu, perlu dilakukan kegiatan bersama sebagai wadah untuk memperkuat komitmen generasi muda terhadap ajaran agamanya masing-masing yang selaras dengan upaya memperkuat komitmen mereka terhadap keutuhan Negara Kesatuan Republik Indonesia.

Ruang dialog pemuda umat beragama menjadi sesuatu yang penting dan harus diupayakan terus menerus. Sebab, keberadaan pemuda dengan emosi yang masih labil mudah tersulut dengan gesekan-gesekan atas nama agama. Oleh karena itu, ruang dialog 
menjadi sebuah keharusan dalam ihtir menjaga dan merawat kerukunan sesama anak bangsa.

Kegiatan Forum Dialog Generasi Muda Umat Beragama dimaksudkan untuk memfasilitasi pemuda lintas agama untuk bersama-sama menggalang persatuan dan kesatuan dalam mewujudkan kerukunan nasional. Adapun tujuan dari ruang dialog tersebut adalah :

1. Menanamkan nilai-nilai kebangsaan, sikap toleransi, dan kebersamaan kepada generasi muda.

2. Memberikan pemahaman kepada generasi muda pentingnya sikap menerima setiap perbedaan suku, agama, ras, dan antar golongan dalam realitas kehidupan bermasyarakat, berbangsa, dan bernegara.

3. Meningkatkan pemahaman wawasan kebangsaan sebagai landasan pola pikir dan pola sikap generasi muda.

Setelah melalui proses sharing yang berjalan secara dialogis dan konstruktif, didapat rumusan pokok-pokok pikiran tentang kehidupan toleransi umat beragama, yang diharapkan bisa menjadi masukan dalam perumusan kebijakan khususnya terkait peningkatan peran generasi muda dalam turut menjaga dan meningkatkan toleransi serta kerukunan antar umat beragama. Diantara rumusan tersebut adalah :

a. Kemajemukan masyarakat beragama

1. Kemajemukan jika dipandang secara bijaksana bisa menjadi salah satu poin positif untuk Negara Kesatuan Republik Indonesia (NKRI). Sebab keberagaman adalah hal yang indah, asalkan masing-masing pemeluk agama menjalankan ajaran dan ibadahnya dengan sungguh-sungguh, tanpa menyinggung/ mengganggu ibadah pemeluk agama yang lain;

2. Namun seiring perkembangan jaman dengan berbagai tuntutan hidup yang semakin menambah kesibukan individu, sering dijadikan alasan pembenar untuk tidak menjalankan ibadahnya secara utuh sehingga tampaknya muncul dua kelompok masyarakat beragama. Masyarakat yang jelas beragama dan rajin beribadah ke tempat ibadah yang notabene lebih mudah dirangkul, kelompok lainnya adalah yang "abu-abu", mengaku beragama tetapi tidak menjalankan ibadahnya secara utuh dan jarang beribadah ke tempat ibadah sehingga sulit untuk dilakukan pendekatan; 
3. Dalam masing-masing agama sendiri masih banyak pentafsiran yang berbeda, sehingga menjadi kendala bagaimana bisa saling berkomunikasi dengan pihak lain, jika sesama saja masih belum satu;

4. Saat perayaan hari besar agama, tercipta toleransi dengan saling menjaga keamanan dan ketertiban tempat ibadah meskipun oleh pemeluk agama yang lain, namun sering mendapat kritikan dari kelompok lain dan dianggap menyalahi ajaran agama yang ada. Namun yang harus diingat bahwa yang penting disini adalah bahwa negara menjamin kemerdekaan penduduk, jadi sudah kewajiban masing-masing agama sebagai bagian dari elemen penyelenggara Negara untuk ikut menjaga keutuhan NKRI;

5. Untuk itu perlu diselenggarakan dialog-dialog lintas agama sebagai sarana untuk menjembatani perbedaan. Semakin banyak tahu semakin sedikit curiga, semakin sedikit tahu semakin banyak curiga.

b. Radikalisme negatif dan aliran sempalan:

Perkembangan jaman yang juga mengakibatkan cepatnya perkembangan di dunia teknik informasi dan telekomunikasi, semakin menafikan batas-batas antar bangsa dan Negara, sehingga ikut memberikan pengaruh terhadap cara pandang dan bersikap generasi muda yang terlahir di era digital seperti sekarang ini terhadap ajaran agama. Tidak tertutup kemungkinan mereka terpengaruh ajaran radikal negatif yang menyimpang dari ajaran agama yang murni, juga menyimpang dari ideologi Negara Kesatuan Republik Indonesia (NKRI) sehingga muncul aliran-aliran sempalan dan radikal negative di tengah masyarakat;

c. Peran generasi muda dalam menciptakan kerukunan umat beragama:

1. Generasi muda merupakan generasi penerus dalam membina kerukunan, jangan sebaliknya malah menyebabkan ketidakrukunan. Dari peristiwa konflik berlatar belakang SARA, tidak jarang ada keterlibatan pemuda, termasuk para pelaku bom bunuh diri. Pemuda harus dapat berperan untuk masa depan dengan mempertahankan tradisi juga menjadi pemutus rantai konflik.

2. Perlu membangun komunikasi dengan membentuk wadah kepemudaan lintas agama, sebagai upaya membangun sebuah blue print kerukunan di masa depan.

Oleh karena itu, ruang dialog kerukunan antar generasi umat bergama menjadi penting. Dan nantinya hasil dari dialog tersebut dapat menjadikan rujukan khususnya 
bagi pemerintah dalam upaya menjaga dan mentransformasikan nilai keberagamaan di tengah-tengah masyarakat. Adapun masukanya diantaranya adalah :

1. Diperlukan transfer pengetahuan terkait kearifan lokal dari generasi terdahulu kepada generasi muda, agar kearifan lokal yang telah menjadi akar dalam kehidupan sosial dan budaya masyarakat tidak luntur, namun dapat terus terjaga guna mengimbangi dengan kebudayaan modern yang kian besar pengaruhnya kepada generasi muda sekarang ini;

2. Dibutuhkan kesadaran bersama untuk membangun pendidikan yang inklusif, yang tidak semakin menajamkan perbedaan yang ada namun sebaliknya dapat membantu terciptanya pemahaman yang lebih baik terhadap masing-masing agama, budaya, dan kemajemukan lainnya, tanpa harus membenturkan perbedaan yang ada;

3. Dibutuhkan kode etik bersama dalam menyikapi perkembangan kehidupan beragama, yang terkadang tidak sesuai dengan ajaran agama yang telah dianut masyarakat selama ini, secara lebih arif dan bijaksana, dengan mengedepankan musyawarah dan menghindari konflik terbuka yang dapat menimbulkan dampak kerugian sosial yang sangat besar;

4. Menghajatkan tumbuhnya kesadaran dari para politisi, untuk tidak mencampur adukkan kepentingan politik dengan kepentingan agama atau kepentingan lainnya, jika ingin mempersiapkan generasi muda sebagai politisi masa depan yang berkompeten dan memiliki integritas tinggi terhadap perbaikan kehidupan bermasyarakat, berbangsa dan bernegara di dalam wadah Negara Kesatuan Republik Indonesia.

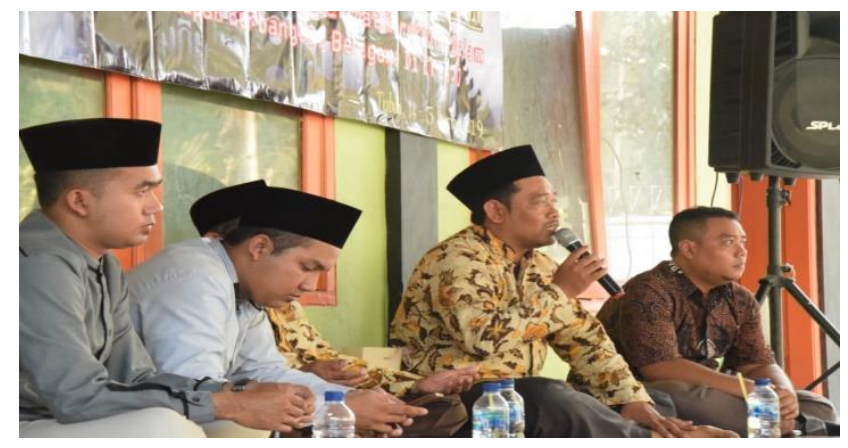

Foto : Dialog Generasi Umat Beragama

\section{Media Sosial}

Media sosial tidak bisa dipungkiri berhasil memberikan warna baru dalam setiapaspek kehidupan, mulai dari aspek perpolitikan, sosial, budaya hingga agama. Kemudahan menjadi salah satu kata kunci penting yang mampu mempresentasikan realitas tersebut. Dalam 
konteks agama misalkan materi-materi keagamaan akan mudah didapatkan dengan sekali tekan tombol "mencari". Pengguna media sosial akan secara cepat tersuguhi materi-materi keagamaan sesuai yang diinginkan, atau dengan tombol sebar seorang pengguna bisa secara langsung 'memasarkan' materi-materi keagamaan ke khalayak. Materi-materi tersebut bisa berupa artikel, vidio ceramah, meme atau gambar dan sebagainya. Semua terjadi serba mudah, cepat dan instan (Mudin, 2019; 145).

Dengan kecanggihan media saat ini, kita dapat memanfaatkan momen tersebut dengan mengkampanyakan nilai-nilai tasamuh dalam keberagamaan. Semua lini bersama-bersama memenuhi media sosial dengan konten yang merujuk pada kerukunan dalam perbedaan. Maka, apabila hal tersebut terus menerus dilakukan oleh generasi milenial maka akan terbentuk citra positif dalam relasai keberagamaan kita.

Media sosial dengan berbagai fasilitasnya yang memudahkan pada akhirnya harus diakui tidak hanya sebagai wadah dan ruang hiburan, melainkan menjadi ruang distribusi atau ruang transformasi pengetahuan agama (Mudin, 2019 ; 217). Dalam hal ini, transformasi nilai keragamaan dalam keberagamaan muncul dalam ragam bentuk dan model. Digitalisasi literatur dan programisasi yang merujuk pada nilai keragaman budaya,sosial,dan agama. Adanya video yang menjadi sarana audioisasi dan visualisasi kampaye kerukunan. Desain gambar atau meme yang merupakan bentuk visualisasi nilai keragaman yang dapat didapatkan pada berbagai jenis media sosial misalnya : Facebook, WhatsApp, Instagram, Line, Twitter, Blog, dan sebaginya. Itulah pentingnya media sosial dalam upaya transformasi nilai keragaman dalam keberagamaan pada generasi milenial. Sebab, disadari maupun tidak. Generasi tersebutlah yang banyak mengakses media-media tersebut.

\section{Ruang Publik, Caffe, Warung Kopi}

Untuk menembus ruang kehidupan generasi milenial, saat ini banyak sekali ruang publik yang menjadi rujukan para pemuda mislanya caffe atau warung kopi. Keberadaan warung kopi di suatu daerah sangat banyak sekali, sampai masuk pada ruang-ruang pedesan yang jauh dari perkotan. Dari analisa tersebut dapat diambil kesimpulan bahwasanya banyaknya para penikmat kopi didominasi oleh kaum muda.

Dari sinilah ada ruang gerak dalam transformasi nilai keberagaman dalam keberagamaan. Warung-warung kopi tersebut dapat dijadikan sarana sosialisasi dan transformasi nilai pentingnya penguatan persatuan dan kesatuan dalam bingkai Negara kesatuan Republik Indonesia (NKRI) baik dengan menyebarkan pamflet kerukunan, brosur keberagamaan, dan panggung kreasi anak bangsa. Yang nantinya dimasuki nilai-nilai keharmonisan dalam kehidupan berbangsa, bernegara, dan beragama di bawah panji Bhineka Tunggal Ika. 


\section{PENUTUP}

\section{Kesimpulan}

Dengan ulasan di atas, dapat kita fahami bersama bahwasanya perbedaan adalah sebuah sunnatullah yang tidak dapat dipungkiri oleh seluruh elemen umat beragama. Oleh karena itu, transformasi nilai pendidikan keberagamaan menjadi penting bagi keberlangsungan bangunan peradaban di bumi Nusantara ini. Peranan seluruh anak bangsa tidak terkecuali generasi milenial sebagai ujung tombak estafet kepemimpinan kedepan harus benar-benar memahi peta dan potensi keragaman sebagai sebuah peradaban yang sudah ada sejak lama dan harus dijaga kelestariannya. Penjagaan dan perawatan peradaban Nusantara tersebut dengan mentransformasikan nilai keberagaman dalam keberagamaan pada berbagai sisi kehidupan. Baik pada wilayah institusi pendidikan dengan dialog, seminar, dan kerjasama lainya.

\section{REFERENSI}

Aslan, Adnan. 2004. Pluralisme Agama dalam Filsafat Islam Kristen Seyyed Hossein Nasr, John Hick, Menyingkap Kebenaran. Bandung : Alifya

Azra, Azyumardi. 2005. Pluralisme Islam dalam Perspektif Historis'. Dalam Sururin (ed), NilaiNilai Pluralisme dalam Islam, Bingkai Gagasan yang Berserak. Bandung : Nuansa

Ghazali, Moqsith, Abd. 2009. Argumen Pluralisme Agama Membangun Toleransi Berbasis Agama. Depok : KataKita

Daulay, Hamdan. 2001. Dakwah Di Tengah Persoalan Budaya Dan Politik. Yogyakarta : LESFI

Ghofir, Jamal. 2017. Nilai Toleransi dalam Dakwah Nabi Muhammad SAW, Menyingkap Pesan Damai Piagam Madinah. Yogyakarta : Dialektika

Irawan, Aguk. 2018. Akar Sejarah Etika Pesantren di Nusantara, Dari Era Sriwijaya sampai Pesantren Tebu Ireng dan Ploso. Tanggerang : Pustaka Iiman.

Kimbali, Carles. 2003. Kala Agama Menjadi Bencana, ter Nurhadi. Bandung : Mizan

Mudin, Miskin. 2019. Islam Vertual, Diskursus Hadis, Otoritas, Dan Dinamika Kebersilaman Di Media Sosial. Yogyakarta : Bildung

Mutakhim, Imam. 2016. Mengelola Keragaman Di Sekolah Gagasan dan Pengalaman Guru. Yogyakarta : CRCS

Naim, Ngainun. 2014. Islam dan Pluralisme Agama. Yogyakarta : Aura Pustaka

Nasr, Hosesein, Sayyed. 2003. The Heart of Islam; Pesan-Pesan Universal Islam untuk Kemanusiaan. alih bahasa Nurasiah Fakih Sutan Harahap. Bandung : Mizan.

Pohan, Asril, Rahmad. 2014. Toleransi Inklusif, Menapak Jejak Sejarah Kebebasan Beragama dalam Piagam Madinah. Yogyakarta :Kaukaba 
Qomar, Mujamil. 2012. Pemikiran Islam Metodologi, Model Pemikiran Alternatif dalam Memajukan Peradaban Islam. Yogyakarta : Teras)

Rachman, Munawar, Budi. 2001. Islam Pluralis. Jakarta : Paramadina

Rahkmat, Jalaluddin. 2006. Islam dan Pluralisme, Akhlak al-Qur'an Menyikapi perbedaan. Jakarta : Serambi

Siroj, Aqil, Said. 2014. Islam Sumber Inspirasi Budaya Nusantara Menuju Masyarakat Mutamadun. Jakarta : LTN NU.

Yasid, Abu. 2018. Paradigma Baru Pesantren Menuju Pendidikan Islam Transformatif. Yogyakarta : IRCiSoD. 